\title{
РАЗДЕЛХІ. ЮРИСПРУДЕНЦИЯ
}

\author{
Кузнецова М.В. \\ Правовая природа российских судебных актов в сфере труда \\ Восточно-Сибирский филиал Российского государственного университета правосудия
} (Россия, Иркутск)

doi $10.18411 /$ scc-05-2018-29

idsp 000001:scc-05-2018-29

Вопрос о правовой природе судебных актов дискутируется очень давно. Впервые предложение считать постановления Пленума Верховного Суда СССР своеобразными нормативными подзаконными актами и, следовательно, источниками права высказал П.Е. Орловский в 1940 г., впоследствии к нему присоединились М.М. Исаев и М.Д. Шаргородский. В то же время И.Б. Новицкий и И.С. Тишкевич категорически отрицали принадлежность каких-либо судебных актов к источникам права .

В современной научной и даже учебной литературе по трудовому праву единство мнений по этому вопросу также отсутствует: одни авторы считают постановления пленумов высших судов источниками права, другие не рассматривают указанные акты в качестве таковых .

Противники признания постановлений пленумов высших судов источниками права аргументируют свою точку зрения с различных позиций . Однако, их аргументы не представляются убедительными. Было бы весьма странным, если бы при рассмотрении, например, трудовых дел суды не считались с указами Президента РФ, постановлениями Правительства РФ и всеми остальными нормативными правовыми актами, содержащими нормы трудового права, упомянутыми в ст. 5 ТК РФ. Отсутствие в ст. 126 Конституции указания на обязательный характер разъяснений Верховного Суда также ни о чем не говорит, поскольку давать необязательные разъяснения может кто угодно кому угодно, и упоминать об этом в Конституции было бы совершенно излишне. Такое упоминание означает именно то, что данные разъяснения обязательны. Правда, в этой статье упоминаются только разъяснения по вопросам судебной практики, и отсюда можно сделать вывод, что они обязательны только для судов. Однако, поскольку в настоящее время любой спор о праве (во всяком случае, в сфере регулирования труда) может закончиться в суде, обязательность для судов означает фактически обязательность для всех .

Принцип разделения властей тоже не следует понимать буквально. Как указывает М.Н. Марченко, опыт других стран (в частности, США) давно и плодотворно использующих принцип разделения властей, демонстрирует, что жесткое, строгое, изначально заданное разделение сферы деятельности различных ветвей власти существует лишь в теории, но не в реальной жизни[1] . Кроме того, этот принцип был сформулирован в свое время главным образом с целью не допустить доминирования одной из ветвей власти за счет подавления других. Между тем, как показывает мировой опыт, склонна к этому отнюдь не судебная власть, а исполнительная, право которой на подзаконное нормотворчество никем не оспаривается (и которым она частенько злоупотребляет).

Наконец, существует Федеральный конституционный закон от 31 декабря 1996 г. N 1-ФКЗ "О судебной системе Российской Федерации" . Часть 1 ст. 6 этого Закона гласит: "Вступившие в законную силу постановления федеральных судов... являются обязательными для всех без исключения органов государственной власти, органов местного самоуправления, общественных объединений, должностных лиц, других физических и юридических лиц и подлежат неукоснительному исполнению на всей территории Российской Федерации". Таким образом, если разъяснения Верховного Суда или Высшего Арбитражного Суда оформлены в виде постановлений, их общеобязательность вытекает и из этого Конституционного закона. 
Сторонники этой позиции, не отрицая обязательного характера постановлений Пленума и признавая их нормативными правовыми актами, не считают их, тем не менее, источниками права, поскольку они не должны содержать новых норм, а только толковать существующие. А.Ф. Черданцев предлагает называть эти акты интерпретационными [2].

Рассмотрим эту точку зрения более подробно. В литературе по теории права подчеркивается, что ясного ответа на вопрос, где та грань, за которой кончается разъяснение и начинается уже, по сути дела, нормотворчество, юридическая наука не дает . В.И. Каминская полагала, что сам процесс толкования норм права содержит в себе правотворческие элементы, поскольку толкование раскрывает и детализирует положения закона, содержавшиеся в нем до этого в скрытом виде . С точки зрения реализации права акты официального нормативного толкования (не обязательно судебного) и подзаконного нормотворчества практически тождественны. И те, и другие содержат общеобязательные правила, рассчитанные на неопределенный круг лиц и неограниченное количество случаев применения, и те, и другие не должны противоречить законам.

Возникает вопрос, а есть ли вообще упомянутая грань, где кончается разъяснение и начинается подзаконное нормотворчество, то есть конкретизация норм закона нижестоящими нормативно-правовыми актами? Общеизвестно, что федеральные законы конкретизируют нормы Конституции, однако нельзя же считать единственным "настоящим" источником права только последнюю, а законы лишь официальным нормативным толкованием .

В идеале такая грань есть. Официальное нормативное толкование, как и всякое другое толкование, это уяснение и разъяснение смысла правовой нормы, выявление подлинной воли законодателя. Подзаконное же нормотворчество решает вопрос, по которому законодатель не счел нужным выразить свою волю и явно или неявно управомочил создать соответствующую норму иной субъект (как правило, орган исполнительной власти). Можно привести следующие примеры: ст. 253 ТК РФ запрещает применение труда женщин на работах, связанных с подъемом и перемещением вручную тяжестей, превышающих предельно допустимые для них нормы, причем предельно допустимые нормы нагрузок для женщин при подъеме и перемещении тяжестей вручную утверждаются в порядке, установленном Правительством Российской Федерации с учетом мнения Российской трехсторонней комиссии по регулированию социально-трудовых отношений. Здесь законодатель в явном виде поручает Правительству принять подзаконный акт, содержащий конкретные величины предельно допустимых нагрузок. Примером неявного поручения может служить многократно упоминаемый в Трудовом кодексе "орган, осуществляющий государственный надзор и контроль за соблюдением трудового законодательства и иных нормативных правовых актов, содержащих нормы трудового права". Ясно, что для того, чтобы соответствующие нормы могли действовать, необходим подзаконный акт, предусматривающий, какой именно орган этим занимается. Очевидно, что никакими известными способами толкования правовых норм решить подобные вопросы невозможно.

На практике, однако, разграничить нормативное толкование и конкретизацию закона нормами, хотя и соответствующими общему смыслу закона, его цели, но в то же время являющимися новыми, зачастую невозможно. Доказательством тому, как указывали С.Н. Братусь и А.Б. Венгеров, служат многочисленные случаи последующего восприятия многих правоположений, выработанных судебной практикой, законом[3]. Они задавали естественный вопрос: если бы положения, в частности постановлений пленумов высших судов, не содержали новых норм, зачем вводить их в новые законы? Множество примеров этого, относящихся к трудовому законодательству 20 - 70 гг. прошлого века, приведены А.К. Безиной и В.И. Никитинским [4].

То же самое происходит и ныне. Трудовой кодекс воспринял ряд положений Постановления Пленума Верховного Суда РФ от 22 декабря 1992 г. "О некоторых вопросах применения судами Российской Федерации законодательства при разрешении трудовых споров" (утратил силу в связи с изданием Постановления Пленума Верховного Суда РФ от 17 марта 2004 г. N 2). Так, в ст. 72 ТК РФ воспроизведено 
определение перевода на другую работу, данное п. 12 указанного Постановления, а также предусмотренное этим пунктом требование о письменной форме согласия работника на перевод. Статья 11 ТК РФ восприняла, хотя и в несколько измененном виде, положение п. 50.1 Постановления , определяющего сферу действия трудового права в условиях рыночной экономики, основанной на многообразии форм собственности с преобладанием частной.

Еще больше примеров такого заимствования из Постановления Пленума Верховного Суда РФ от 17 марта 2004 г. N 2 "О применении судами Российской Федерации Трудового кодекса Российской Федерации" содержит принятый Государственной Думой в июне 2006 г. Федеральный закон о внесении изменений в Трудовой кодекс:

- в ст. 57 исключено из числа обязательных условий трудового договора указание структурного подразделения при определении места работы, если оно не является обособленным (последняя часть п. 16 Постановления предусматривала, что указание структурного подразделения можно не включать в трудовой договор);

- в Кодекс вводится новая статья 72.2, ч. 2 и 3 которой воспроизводят толкование Пленумом ст. 74 действующего Кодекса (п. 17 Постановления);

- в подп. "а" п. 6 ст. 81 воспроизводится указание Пленума (п. 39 Постановления) о том, что прогулом является отсутствие на рабочем месте не только более четырех часов, но и в течение всего рабочего дня, даже если он короче четырех часов;

- в подп. "б" П. 6 ст. 81 внесено указание, что основанием увольнения является появление в состоянии опьянения не только на своем рабочем месте, но и на территории организации-работодателя или объекта, где по поручению работодателя работник должен выполнять трудовую функцию, как и истолковал данное основание Пленум (п. 42 Постановления);

- в ч. 2 ст. 81 закреплено положение, что порядок проведения аттестации (при увольнении по п. 3 ч. 1 этой статьи) устанавливается трудовым законодательством и иными нормативными правовыми актами, содержащими нормы трудового права, локальными нормативными актами (п. 31 Постановления);

- в ч. 3 данной статьи уточняется норма о предложении другой работы при увольнении по сокращению численности или штата - указано, что предлагать надо не только работу, соответствующую специальности и квалификации, но и менее квалифицированную (п. 29 Постановления );

- в ст. 142 указывается, что в период приостановления работы вследствие задержки заработной платы работник имеет право в свое рабочее время отсутствовать на рабочем месте, на что обращал внимание Пленум (п. 57 Постановления );

Это также неочевидно - в судебной практике (до издания указанного Постановления) встречались случаи, когда признавалось законным увольнение за прогул работника, приостановившего работу и не вышедшего на нее.

— в ст. 192 дается перечень оснований увольнения, являющихся дисциплинарными взысканиями (п. 47 и 52 Постановления), а также указано, что при наложении дисциплинарного взыскания должны учитываться тяжесть совершенного проступка и обстоятельства, при которых он совершен (п. 53 Постановления).

В литературе по теории права отмечалось, что "осуществляя официальное нормативное толкование права, высшие судебные органы могут только разъяснять содержание толкуемых норм права. Вносить же в них какие-либо изменения и дополнения или создавать новые нормы права они не правомочны, поскольку это является уже прерогативой правотворческих органов" . С тем, что положения постановлений пленумов высших судов не должны изменять закон, согласиться можно. Что же касается дополнений, конкретизации закона, то, учитывая изложенное выше, 
приходится признать, что, как показывает многолетняя практика, в определенных случаях это, видимо, неизбежно. В.М. Жуйков полагает, что в современных условиях суды зачастую вынуждены и должны создавать (творить) право, иначе их деятельность станет не просто неэффективной, а приведет к результатам, противоположным тем, которые от них вправе ожидать общество: они будут не защищать права, а способствовать их нарушениям .

Таким образом, как представляется, постановления пленумов высших судов следует считать своеобразными подзаконными нормативными правовыми актами, источниками трудового права.

Причем иные подзаконные акты (в том числе нормативные правовые акты Президента РФ и нормативные правовые акты Правительства РФ) могут быть признаны Верховным Судом противоречащими федеральным законам и не подлежащими применению , как, например, это было сделано в отношении некоторых пунктов Положения о дисциплине работников железнодорожного транспорта , объявить же постановление собственного Пленума противоречащим законам и не подлежащим применению Верховный Суд не может. Поэтому следует согласиться с Н.Н. Вопленко и А.П. Рожновым, которые полагают, что необходимо законодательно предусмотреть возможность обжалования в Конституционный Суд РФ руководящих разъяснений Пленумов Верховного Суда РФ и Высшего Арбитражного Суда РФ [5].

Возникает также вопрос об обратной силе указанных актов. А.Ф. Черданцев категорически утверждает: "Общепризнано, что интерпретационные акты имеют обратную силу. Пределы ее определены моментом вступления в действие самой интерпретируемой нормы" . Теоретически это так, ведь норма существовала и раньше, только не все ее правильно понимали. Однако, как подчеркивалось выше, грань между официальным нормативным толкованием и нормотворчеством очень тонкая, сам же А.Ф. Черданцев признает, что в определенных случаях правило, сформулированное в разъяснениях, начинает функционировать как норма права, изданная законодателем . Возникает вопрос: как быть, если эта новая норма (или даже неочевидное толкование) устанавливает или ужесточает ответственность? Ведь в соответствии со ст. 54 Конституции РФ такие законы обратной силы не имеют. В качестве примера можно привести упомянутый выше п. 39 Постановления Пленума ВС РФ от 17 марта 2004 г. Фактически здесь содержится новая норма (не зря ее предполагают включить в ТК), ужесточающая ответственность. Формулировка действующей редакции п. 6 ч. 1 ст. 81 ТК относит к однократным грубым нарушениям трудовых обязанностей, за которые возможно увольнение, "прогул (отсутствие на рабочем месте без уважительных причин более четырех часов подряд в течение рабочего дня)". Поскольку какого-либо иного определения понятия "прогул" Кодекс не содержит, эта формулировка не дает, как представляется, достаточных оснований полагать, что прогулом является отсутствие на рабочем месте не только более четырех часов, но и в течение всего рабочего дня, даже если он короче четырех часов, как предлагает считать Пленум. Видимо, следует полагать, что в подобных случаях акты официального нормативного толкования не должны иметь обратной силы.

$$
* * *
$$

1. Марченко М.Н. Источники права: Учебное пособие. М., 2005. с. 127

2. Черданцев А.Ф. Толкование права и договора. М., 2003. с. 251

3. Братусь С.Н., Венгеров А.Б. Понятие, содержание и формы судебной практики // Судебная практика в советской правовой системе / Под ред. С.Н. Братуся. М., 1975. с. 30.

4. Безина А.К. и Никитинский В.И. Судебная практика и трудовое право // Судебная практика в советской правовой системе. С. 142 - 172. 2004.

5. Вопленко Н.Н., Рожнов А.П. Правоприменительная практика: понятие, основные черты и функции. Волгоград, 2004. с. 183 